\title{
MIR483 wt Allele
}

National Cancer Institute

\section{Source}

National Cancer Institute. MIR483 wt Allele. NCI Thesaurus. Code C131517.

Human MIR483 wild-type allele is located in the vicinity of 11p15.5 and is approximately 80 bases in length. This allele, which encodes MIR483 pre-miRNA, may play a role in the negative regulation of mRNA translation. Alteration in the expression of this gene may be associated with development of non small lung cell carcinoma. 